\title{
Miksi työmarkkinoiden ja kielikoulutuksen tarpeet eivät kohtaa?
}

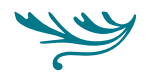

Luopumalla eri kielten lokeroajattelusta ja omaksumalla uudenlainen näkemys kielten opiskeluun tuotettaisiin suurempaa kielitaitohyötyä niin työelämässä kuin sen ulkopuolellakin. Language for Jobs -työryhmä on etsinyt ratkaisuja kielitaitotarpeiden ja kielikoulutuksen tarjonnan kohtaamisen ongelmiin.
\end{abstract}

KOULUTUKSELTA ODOTETAAN YHÄ nopeampaa reagointia yhteiskunnassa tapahtuviin muutoksiin. Koulutuksen odotetaan antavan yksilölle kykyä ja halua kehittää kompetenssejaan ja tätä kautta se nähdään ratkaisuna yhtä lailla maahanmuuttajien integroitumiseen kuin pörssikurssien tahtiin heilahtelevien työmarkkinoiden murroksen hallintaan (ks. Simons \& Masschelein 2008.)

Koulutus on myös yhteiskunnan ongelmanratkaisun lähde. Kun vaikkapa työelämän ja kielikoulutuksen tarpeet ja toteutukset eivät kohtaa, käännytään kielikoulutuksen puoleen: kielikoulutuksen on muututtava.

Koulutususko onkin osittain uskoa muutoksen välttämättömyyteen ja mahdollisuuteen. Koulutuspolitiikan muutokset perustuvat siihen yksinkertaiseen mekaniikkaan, että "muutoksen" (jolla usein tarkoitetaan aktiivista reformia) tarvetta pidetään jotenkin itsestään selvänä (Saarinen \& Välimaa 2012).
Muutosta tarvitaan, jotta asiat kääntyisivät paremmiksi. Muutos esitetään välttämättömänä, mutta lisäksi se, joka pääsee esittämään muutoksen tarvetta, pääsee yleensä myös tekemään ensimmäisen ehdotuksen muutoksen luonteesta (ks. Bacchi 2000).

"Muutoksen" tarve onkin itse asiassa politiikan väline, jolla tuotetaan erilaisia poliittisia tavoitteita ja konstruoidaan erilaisia poliittisia lähestymistapoja (Saarinen \& Välimaa 2012). Ongelmia syntyy, kun osapuolten käsitykset muutoksen tarpeesta ja ratkaisumallista eroavat.

\section{KIELITAITO MERKITSEE}

\section{ERI TILANTEISSA ERI ASIAA}

Työelämän kielitaitotarpeet on hyvä esimerkki tilanteesta, jossa eri politiikkasektoreiden tarpeet ja politiikkatavoitteet eivät kohtaa. Työmarkkinoilla on jo kauan tiedetty, että kielitaito on muutakin kuin yksittäisen kielen mahdollisimman hyvää osaamista 
tai suurten eurooppalaisten kielten tarvetta. Kieli on tilanteista ja varioivaa, ja samoin kielitaito on erilaisia - osittaisiakin - kompetensseja, repertuaareja ja resursseja. Myös yksittäisen kielen tarve työmarkkinoilla saattaa vaihdella erilaisista (suhdanne-)tekijöistä riippuen voimakkaastikin.

Kielikoulutuspolitiikassa näitä työmarkkinoiden tarpeita ratkotaan kuitenkin kielilähtöisesti. Ihmetellään, miksi lapset eivät halua enää opiskella saksaa, ranskaa tai venäjää, vaikka työmarkkinat niitä tarvitsevat. Ratkaisuksi tarjotaan yksittäisten kielten lisäämistä erilaisin tukiohjelmin, jollaisia ovat esimerkiksi 1990-luvun KIMMOKE tai 2000-luvun POP-hankkeet. Kymmenvuotiaat ja heidän vanhempansa eivät kuitenkaan tee kielivalintoja rationaalisen työmarkkinatarpeen pohjalta, vaan aivan muilla argumenteilla (esimerkiksi Kangasvieri, Miettinen, Kukkonen \& Härmälä 2011).

Kouluopetuksen kielikäsitys ei myöskään tunnu vastaavan työelämän tarpeita. Kielenopetus on pedagogisesti kehittynyt huimasti viime vuosikymmeninä, mutta tästä huolimatta se on edelleen oppiaineja oppikirjalähtöistä, kuten Luukan ja kumppaneiden laajassa Akatemiahankkeessa todettiin (ks. Luukka ym. 2008).

Myöskään suullista kielitaitoa ei kouluopetuksessa harjoiteta työmarkkinoiden tarpeiden kannalta riittävästi. Samaan aikaan kielellisten käytänteiden nähdään entistä enemmän liittyvän tilanteisiin, vuorovaikutuskonteksteihin ja puhujien keskinäisiin resursseihin (Blommaert 2007).

Tarkastelemme tässä artikkelissa tätä eri politiikkasektoreiden periaatteiden ja tavoitteiden kohtaanto-ongelmaa tuomalla yhteen työmarkkinoiden ja (kieli)koulutuspolitiikan viimeaikaisia trendejä Suomessa ja Euroopan unionissa. Keskustelutamme viimeisintä koulutuksen ja tutkimuksen kehittämissuunnitelmaa (OKM 2011), Euroopan unionin komission Languages for Jobs -työryhmän tuoretta loppuraporttia (Languages for Jobs 2011), muita työmarkkina- ja koulutuspolitiikkaraportteja ja -suunnitelmia sekä alan tutkimusta.

\section{TYÖN JA KIELIKOULUTUKSEN MUUTOS}

Työn luonne on muuttunut viime vuosikymmeni- nä merkittävästi muun muassa kansainvälistymisen sekä tieto- ja viestintätekniikassa tapahtuneen kehityksen myötä (Roberts 2010). Yritysten sisäinen ja ulkoinen verkostoituminen edellyttää työntekijöiltä yhä parempia vuorovaikutustaitoja sekä kykyä viestiä taustoiltaan erilaisten ihmisten kanssa. Suuri osa päivittäisestä työstä tapahtuu tiimeissä, joissa hierarkkiset rakenteet ovat kevyempiä kuin perinteisissä organisaatioissa. Seurauksena on ollut aivan uusien kommunikointitapojen ja tekstimuotojen syntyminen. Jopa tekstitaitoisuus on saanut täysin uusia merkityksiä (Lo Bianco 2010). Tapahtunutta muutosta kuvaa se, että perinteisen työvoiman (workforce) sijasta puhutaankin eräänlaisesta puhetta ja tekstejä tuottavasta "sanavoimasta" (wordforce) (Heller 2010, 2005).

Myös koulutuksen edellytetään reagoivan työelämän muutoksiin. Euroopan unionin neuvosto hyväksyikin toukokuussa 2009 eurooppalaisen koulutusyhteistyön strategiset tavoitteet vuodelle 2020 (Eurooppa 2020). Tämän laajemman puiteohjelman tavoitteet ovat eurooppalaisen lennokkaasti

1. tehdä elinikäisestä oppimisesta ja liikkuvuudesta totta;

2. parantaa koulutuksen laatua ja tehokkuutta;

3. edistää tasapuolisuutta, sosiaalista yhteenkuuluvuutta ja aktiivista kansalaisuutta;

4. edistää luovuutta, innovointia ja yrittäjyyttä kaikilla koulutusasteilla.

Yleviin koulutuksen laatua ja tehokkuutta koskeviin eurooppalaisiin tavoitteisiin kuuluu myös kielitaidon vahvistaminen. Siksi onkin tarpeen pohtia, miten koulutuksen tuottamat taidot ja työelämän tarpeet kohtaavat, kun puhutaan kieli- ja viestintätaidoista. Tämä koskee yhtä lailla tälläkin saralla katveeseen jäänyttä ammatillista koulutusta kuin perus,korkea- ja aikuiskoulutusta.

\section{AMMATILLINEN KOULUTUS VS. TYÖMARKKINOIDEN TARPEET}

Työelämässä tapahtuneet yleismaailmalliset muutokset näkyvät myös suomalaisessa työelämässä. Koulutuksessa kerran hankitut tiedot ja taidot vanhenevat nopeasti, eivätkä yksinään riitä takaamaan henkilön työllistymistä. Työntekijän odotetaan jat- 
kuvasti kehittävän ja monipuolistavan omaa osaamistaan. Ammattinimikkeiden sijaan korostetaan entistä enemmän osaamista. Perinteisten, eri ammattien välisten rajojen madaltuessa uusia työ- ja tehtävänimikkeitä syntyy jatkuvasti eri ammattien rajapinnoille. Julkunen $(2009,35)$ nimittääkin parhaillaan menossa olevaa ajanjaksoa jälkiammatilliseksi työelämäksi, jolle on ominaista ammattinimikkeiden epämääräistyminen, ammattirajojen rikkoutuminen ja entistä suurempi tarve työntekijän monitaitoisuudelle. Ammatti-identiteetin sijasta voidaankin nykyisin

Kielivalintojen JA

KIELTEN OPISKELUN V ̈̈HENEMINEN

PERUSOPETUKSESSA

\section{N ̈̈YTT $\ddot{A}$ OLEVAN}

\section{YLEISEUROOPPALAINEN}

TRENDI. puhua työidentiteetistä

(Eteläpelto 2009), joka on käsitteenä huomattavasti laajempi sisältäen muun muassa organisaation arvoja ja tavoitteita.

Ammatillista koulutusta kritisoidaan usein hitaasta reagoinnista työelämän muutoksiin. Vaikka koulutustarjontaa, esimerkiksi opiskelijapaikkojen lukumäärää eri aloilla, pyritään suuntaamaan työelämän tarpeiden mukaisesti, koulutussisältöjen laadullinen ennakointi on huomattavasti ongelmallisempaa. Esimerkiksi toisen asteen ammatillista koulutusta luonnehtii pirstaleisuus sekä tutkintojen lukumäärän että tutkintoja järjestävien organisaatioiden perusteella arvioituna. Erilaisia perustutkintoja on nykyään yhteensä 53 ja niiden lisäksi aikuiskoulutuksessa on mahdollisuus suorittaa noin 300 eri ammatti- ja erikoisammattitutkintoa. Päällekkäiskoulutuksen vähentämiseksi kaivataankin nykyistä joustavampia opetusjärjestelyitä ja mahdollisuutta suorittaa vain osia tutkinnoista. (OKM 2011.) Tutkintojen moduulirakenne antaa tutkinnon suorittajalle ainakin periaatteessa mahdollisuuden koota tutkintojen sisällöistä itselleen parhaiten soveltuvan osaamiskokonaisuuden. Mielenkiintoista olisikin tietää, missä määrin tätä mahdollisuutta myös käytetään ja erityyppistä osaamista tunnustetaan esimerkiksi uuden työntekijän rekrytointitilanteessa.

Suomalaisessa työelämässä arvostetaan muodol- lisessa koulutuksessa suoritettuja tutkintoja, joskin samaan aikaan tunnustetaan myös koulutusjärjestelmän tehottomuus, mikä ilmenee muiden muassa pitkinä opiskeluaikoina (OKM 2011,9-10). Kun väestön osaamistaso suoritettujen tutkintojen määrissä mitattuna on noussut, on myös tutkintojen arvo kokenut inflaation. Esimerkiksi kaupan kassalla voi nykyisin työskennellä sekä toisen asteen ammatillisen perustutkinnon suorittanut merkonomi että korkeakoulututkinnon suorittanut tradenomi. Vaikka heidän osaamisessaan on paljon yhteistä, voidaan myös kysyä, minkä verran tradenomin osaamispotentiaalista jää hyödyntämättä kyseisessä työtehtävässä.

Ammatillinen osaaminen ja ammattitaito liitetäänkin nykyisin yksilön kompetenssin kuvaamiseen, ei niinkään työn edellyttämiin kvalifikaatioihin. Kun yksilön edellytetään koko ajan hankkivan itselleen uutta osaamista ja kehittävän itseään, työtehtävien räätälöinti myös työntekijän osaamiseen perustuen tulee yhä yleisemmäksi.

\section{MONIAMMATILLISTA KIELITAITOA}

Työelämässä tarvittava kielitaito on viime aikoina noussut esille ennen kaikkea maahanmuuttajataustaisten työntekijöiden suomen kielen taidon riittävyyttä pohdittaessa. Eri aloilla tarvittavaa suomen kielen taitoa on selvitetty useissa eri tutkimuksissa ja tutkimushankkeissa (esimerkiksi Virtanen 2010). On kartoitettu muun muassa eri alojen keskeisiä kielenkäyttötilanteita ja niissä tarvittavaa kielitaitoa sekä sitä, tulisiko suomen kieltä opiskella jo ennen työelämään sijoittumista vai vasta työelämässä (Kela \& Komppa 2011).

Mitä sitten tarkoitetaan, kun puhutaan työelämässä tarvittavasta kielitaidosta? Miten työelämässä tarvittava kielitaito eroaa niin sanotusta yleiskielitaidosta vai eroaako juurikaan muutoin kuin tietyn alakohtaisen sanaston korostumisella? Käsitteen 
epämääräisyyttä kuvastavat ne eri nimitykset, joilla samaan asiaan eri yhteyksissä viitataan: työkieli, ammattikieli, ammatillisesti suuntautunut kielitaito, erityisalan kieli, professionaalinen kieli- ja viestintätaito jne. Vaikka samasta asiasta puhutaankin hieman eri nimillä eri tilanteissa, yhteistä kaikille on kielitaitokäsitteen laaja-alaistuminen. Kielitaitoon kuuluu oleellisesti myös vieraiden kulttuurien ja elintapojen tuntemus. Kulttuurisesta osaamisesta on nykyisessä työelämässä tullutkin yksi menestyksen elinehto.

Työelämässä tarvittavia kieli- ja viestintätaitoja voitaisiinkin nykyistä enemmän ajatella eräänlaisena moniammatillisena yleistaitona. Tämä tarkoittaa, että esimerkiksi sairaanhoitajien, insinöörien ja tradenomien tarvitsemassa kielitaidossa on paljon yhteistä, alasta riippumatonta kielellistä osaamista, jonka taitaminen puolestaan helpottaa tehtävästä toiseen siirtymistä. Esimerkiksi Hanhinen (2010) luokittelee kielitaidon "toimialariippumattomaksi tuotannon yleisosaamiseksi”. Tällöin esimerkiksi äidinkielen taito - jolla tietysti useimmiten tarkoitetaan suomen kielen taitoa - katsotaan sellaiseksi perustavanlaatuiseksi taidoksi, jota edellytetään jossain määrin kaikissa työtehtävissä. Myös vieraiden kielten taito on Hanhisen mukaan tällaista osaamista ja siten rinnastettavissa esimerkiksi tietotekniseen osaamiseen, laatuosaamiseen ja projektityöskentelyvalmiuksiin.

\section{KYSYNNÄN JA TARJONNAN ONGELMALLINEN SUHDE}

Suomalaiset kielitaidon ja työelämän kohtaamattomuuskysymykset eivät ole eurooppalaisittain mitenkään ainutlaatuisia. EU:n komissio asetti vuoden 2010 alkupuolella avoimen koordinaatiomenetelmän työryhmän Languages for Jobs pohtimaan kielitaidon ja työelämän yhteyksiä. Työryhmä pohti kielitaidon ja työelämän yhteyksiä osana strategiatyötä runsaan vuoden ajan, ja sen raportti "Languages for Jobs: providing multilingual communication skills for the labour market" valmistui kesällä 2011 (Languages for Jobs 2011).

Ryhmän jäsenet edustivat eri EU-maiden ministeriöitä, tutkimuslaitoksia ja EU-organisaatioita. Kokouksissa keskusteltiin, käytiin läpi tekstejä, kom- mentoitiin ja viilattiin niitä, ja luonnollisesti jokainen toi kokouksiin omat keppihevosensa. Kokouksissa konkretisoitui myös eri maiden kielenopetuksen varsin erilainen tilanne, jos tosin myös yhtäläisiä ongelmia löytyi. Kielivalintojen ja kielten opiskelun väheneminen perusopetuksessa näyttää olevan yleiseurooppalainen trendi.

Asetetun tavoitteen mukaisesti Languages for Jobs -ryhmä pyrkii löytämään ratkaisun kielikoulutuksen ja työelämän kysynnän ja tarjonnan väliseen epäsuhtaan: työmarkkinat tarvitsevat kieli- ja kommunikaatiotaitoja, mutta koulutusmarkkinoiden tarjonta ei täytä tarvetta. Tämä lähtökohta herätti ryhmässä työn alkuvaiheissa paljon keskustelua, kun osa ryhmän jäsenistä epäili suoraviivaisen kysyntätarjonta -jaottelun toimivuutta.

Keskeinen kysymys oli, miten eurooppalaisen työvoiman kielitaitoa tulisi parantaa. Kielikoulutuksen kehittämisen hahmottaminen kysynnän ja tarjonnan kautta on havaittu ongelmalliseksi 1970-luvulta lähtien, kun sekä työmarkkinoiden että niillä liikkuvien ihmisten havaittiin toimivan erilaisten ennakointien vastaisesti.

Myös kielitaidon käsitteestä käytiin keskustelua. Ryhmän puheenjohtaja Harald Hartung halusi aluksi rajata ryhmän työskentelyn - ilmeisesti saamansa toimeksiannon pohjalta - vain niin sanottuihin (kouluissa opiskeltaviin) vieraisiin kieliin, mutta ryhmän jäsenet toivat keskusteluun sekä paikalliset että maahanmuuttajien kielet. Samoin piti avata kielitaidon käsitettä, kun erilaiset kommunikaatiotaidot uhkasivat alussa jäädä keskustelussa sivuraiteille. Kielten ammattilaisille onkin työsarkaa: argumentiksi kun ei riitä suoraviivainen lausuma "kieli on kommunikaatiota”. Ryhmäläiset kokivatkin toimeksiannon tiukan rajauksen työelämän tarpeisiin rajoittavan keskustelua välillä turhan voimakkaasti.

Suositusten lisäksi raporttiin koottiin erilaisia kielenopetuksen hyviä käytänteitä eri maista. Raportin loppuun koottiin paketti tavoitteista ja niiden toteutuksesta.

\section{MUUTTUUKO MIKÄÄN?}

Languages for Jobs -ryhmän suositukset ovat kokouksissa käytyjen keskustelun perusteella sekä kierrä- 
tystä erilaisista EU:n liepeillä ja piirissä toteutetuista hankkeista että ryhmän jäsenten intresseistä nousseita. Keskeiset huomiot ja suositukset ovat suurelta osaltaan tuttuja, mikä vahvistaa käsitystä siitä, että nämä nimenomaiset kesto-ongelmat eivät ole kovin helposti ratkaistavissa.

Raportissa esitetyt keskeiset huomiot ja tavoitteet ovat:

1. Kieli- ja kommunikaatiotaitojen tarve eurooppalaisilla työmarkkinoilla kasvaa.

2. Kysynnän ja tarjonnan välistä aukkoa on pystyttävä supistamaan; koulussa opetettavat kielelliset taidot eivät välttämättä ole työnantajien eniten kaipaamia taitoja.

3. Kommunikaatiotaidot ja kulttuurienväliset taidot on otettava entistä paremmin huomioon kieltenopetuksessa; työnantajille on tärkeää, että koulussa opittava kielitaito on kytkettävissä työelämään.

4. Kehittämistarvetta on erityisesti ammatillisessa koulutuksessa; tämä kehittämistarve heijastuu myös ammatillisen sektorin opettajankoulutukseen. CLILtyyppisen, kieltä ja sisältöä integroivaan opetuksen kehittämiseen on panostettava.

5. Liikkuvuus on edelleen Euroopan taloudellisen kilpailukyvyn kehittämisen näkökulmasta ensiarvoisen tärkeää. Työvoiman liikkuvuuteen tähtääviä poliittisia toimia on voimistettava.

6. Muodollisen koulutusjärjestelmän ulkopuolella hankitun kielitaidon tunnistamisen välineitä tulee kehittää. Eurooppalaisen viitekehyksen (CEFR) laajentaminen työmarkkinoilla tarvittavien taitojen arviointiin on hyödyllinen kehittämissuunta.

7. Englanti ei yksin riitä, vaikka se onkin tärkeä kieli; kilpailukykyetu saavutetaan muilla kielillä.

8. Tarvitaan säännöllisiä selvityksiä ja seurantaa työmarkkinoiden kielitaitotarpeista ja niiden ennakoinnista.

9. Tarvitaan suunnitelmia pysyviksi rakenteiksi, joilla voidaan kehittää työntekijöiden kielitaitoa.
Raportissa suositellaan lisäksi naapurikielten osaamista; useimmat maat käyvät suuren osan ulkomaankaupastaan lähinaapuriensa kanssa. Erityisinä esimerkkeinä tällaisesta alueellisesta intressistä nostettiin Itävalta (tarve venäjän, italian, slovenian, slovakian ja unkarin osaajille) ja Katalonia (tarve ranskan osaajille).

Ryhmän raportti seuraa Euroopan unionin neuvoston suosituksia painottaessaan maahanmuuttajataustaisten lasten kielitaidon merkitystä: asuinmaan kieli on erittäin tärkeä, mutta myös oman kielen oppiminen ja ylläpitäminen on tulevan työllistymisen kannalta tärkeää.

Suomessakin Languages for Jobs -ryhmän työstämät tavoitteet ja suunnitelmat ovat tuttuja. Uusimmassa koulutuksen ja tutkimuksen kehittämissuunnitelmassa (OKM 2011) suomalainen kielikoulutus kytkeytyy lähinnä maahanmuuttajiin ja kansalliskielistrategian kehittämiseen. Kansalliskielistrategian yhteydessä otetaan esille viestintävalmiudet; toisaalta taas perusopetuksen tuntijaon yhteydessä mainittu kieliohjelman monipuolistaminen on perinteisesti tarkoittanut kielivalikoiman laajentamishankkeita. Tavoitteisto pyörii siis sekä Euroopan unionissa että sen jäsenmaissa aika lailla samojen asioiden ympärillä.

\section{LYHYTJÄNTEISYYDEN PEDAGOGIIKKAAN?}

Useat Languages for Jobs -ryhmän ehdotukset tuottavat muutospaineita kieltenopetukseen. Tästä huolimatta raportissa todetaan aivan oikein, että kyse ei ole vain jäsenmaiden opetusministeriöiden asiasta, vaan nyt olisi käynnistettävä monitasoinen ja -alainen dialogi työelämän, koulutuksen, ammatillisten järjestöjen, yhteiskunnallisten toimijoiden ja muiden vastaavien intressiryhmien välillä. Suomessakin on yhtenä keinona koulutuksen ja työelämän välisen kuilun kaventamiseen ehdotettu lisätä opettajien työelämän tuntemusta (esimerkiksi EK 2010).

Kielenopetuksen näkökulmasta ryhmä peräänkuulutti oppijakeskeisyyttä, selkeämpää ammatillista kontekstualisointia erityisesti ammatillisessa koulutuksessa sekä työelämäyhteyksien kaikkinaista tiivistämistä. Tämän puolestaan arveltiin parantavan oppijoiden motivaatiota ja parantavan erilaisten käy- 
tännön mahdollisuuksien hyödyntämistä.

Työryhmän ehdotuksiin sisältyy kuitenkin rakenteellisia ikuisuusongelmia. Työelämässä muutokset tuntuvat tapahtuvan nopeasti, kun taas koulutusjärjestelmää on kritisoitu muutostahmeudesta. Yksi syy tarjonnan ja kysynnän kohtaamattomuuteen voi olla tässä. Mutta onko ratkaisu tähän ikuisuusongelmaan koulutusjärjestelmän rakenteellinen vai sisällöllinen muutos? Vai tarkoittaako tämä toisaalta myös haastetta kielipedagogiikalle? Kielenopetusta on tavattu (tai ainakin opettajat ovat tavanneet) kuvata pitkäjänteisyyttä vaativaksi toiminnaksi, mutta pitäisikö kielipedagogiikassa siirtyä lyhytjänteisyyden pedagogiikkaan: nopeaa kurssitusta, osittaisten repertuaarien opetusta ja täydennystä, täydellisyydentavoittelusta luopumista? Yksi siirtymä tähän suuntaan näkyy jo aikuisten ammatillisissa näyttötutkinnoissa, joissa tutkintotilaisuudessa tarvittava kielitaito pyritään varmistamaan täsmäopetuksella ja intensiiviopiskelulla. Tavoitteena on osoittaa tutkinnossa vaadittu kielitaito, ei hallita kielitaidon koko kirjoa (Härmälä 2008).

Toisaalta pörssikurssien heilahdellessa kielenopetuksessa - esimerkiksi ammatillisessa koulutuksessa - pitäisikin mahdollisesti siirtyä suhdanneherkästä erikoistuneesta kielitaidon opetuksesta yleiseen, enemmän ammattialasta riippumattomaan kieli- ja viestintätaitojen opetukseen. Rohkeutta käyttää kieltä erilaisissa työelämän tilanteissa tulisi lisätä. Ja tällöin kielellä ei tarkoiteta vain yhtä kieltä, vaan monen eri kielen rinnakkaiskäyttöä: että osaa viestiä sitten vaikka eri kieliä yhdistelemällä. Myöskään arkijutustelun merkitystä ei saa unohtaa. Kuuluminen erilaisiin työpaikan epävirallisiin ammatillisiin ja sosiaalisiin ryhmiin on varsinkin maahanmuuttajataustaisen työntekijän integroitumisen kannalta erityisen tärkeää (Martinheikki-Kokko, 2009).

Suullisen kielitaidon tärkeys on perusopetuksessa kirjattu opetussuunnitelmiin. Kuitenkin juuri tämä kielitaidon osa-alue jää perus- ja lukio-opetuksessa osaamissaavutusten arvioinnissa usein vähemmälle huomiolle, esimerkiksi arvioinnin aiheuttamiin kustannuksiin vedoten (ks. esim. Tuokko 2009).

Yleiseurooppalainen viitekehys (EVK) on ollut askel kohti arviointikäytänteiden yhdenmukaistamista koko Euroopan alueella, mutta EVK:ta on myös kritisoitu siitä, että se pyrkii laittamaan kaikki samaan muottiin alueellisia ja rakenteellisia eroavaisuuksia huomioimatta. EVK ei myöskään tarjoa kuvaimia työelämässä tarvittavan kielitaidon arviointiin. Yhteisenä eurooppalaisena viitekehyksenä EVK on kuitenkin käyttökelpoinen työkalu paremman puutteessa. Vastaavanlainen viitekehyshän on olemassa myös eurooppalaisten tutkintojen vertailtavuuden arviointia varten (EQF, European Qualification Framework).

\section{MITEN ERI SEKTORIEN TARPEET KOHTAAVAT - VAI KOHTAAVATKO?}

Ongelmat vaihtelevat, kun niitä tarkastellaan eri sektoreista ja intresseistä käsin. Koulutussektorin näkökulmasta lapset ja nuoret eivät valitse riittävästi vieraita kieliä, mitä ongelmaa ratkaistaan erilaisilla kampanjoilla ja ohjelmilla, joiden pysyvyys ei ulotu juuri niiden rahoituskauden yli. Työmarkkinoilla taas ongelma ei ole pelkästään määrättyä kieltä osaavien henkilöiden puute (useimmiten mainitaan alasta riippuen venäjä, ruotsi ja saksa), vaan myös määrätynlaisen kielitaidon puute (esimerkiksi suullisen kommunikaation taso). Euroopan Unionin tasolla ongelmat ja ratkaisut hahmottuvat 1970-lukulaisesti kysynnän ja tarjonnan termein.

Työmarkkinoiden ja koulutusmarkkinoiden tarpeet ja tavoitteet eivät kohtaa, koska ne ovat yksinkertaisesti lähtökohdiltaan eritasoisia. Kielenopettajia koulutetaan kielilähtöisesti, jolloin opetuksen lisäksi myös opettajaprofession ammattiyhdistysintressit ovat kielilähtöiset. Tässä eivät pedagogiset uudistustarpeet auta. Kieltä ja sisältöä integroivalle opetukselle (content-language integrated learning eli CLIL tai kielikylpy) on kysyntää, mutta osittain riittämättömän opettajankoulutuksen ja osittain kuntien tilanteen vuoksi tarjontaa ei ole riittävästi (Kangasvieri, Miettinen, Palviainen, Saarinen \& Ala-Vähälä ym. 2011). Työmarkkinoiden tarpeiden varaan ei opettajaprofession mielestä kaiketi voi luoda kovin pitkäjänteistä kieltenopettamis-tai oppimisstrategiaa: työelämän tarpeet vaihtelevat nopeammin kuin profession tarpeet. 
Näyttää siis siltä, että työelämän ja kielikoulutuksen kohtaamattomista tarpeista ainakin yksi on sellainen, johon puuttuminen ei hyödyttäisi ainoastaan työelämää, vaan saattaisi muutenkin koitua kielenoppijan eduksi. Opettajankoulutuksen uudistaminen, eri kielten lokeroajattelusta luopuminen ja kaiken kaikkiaan uudenlainen näkemys koko kielten opiskeluun hyödyttäisi sekä työelämässä että työajan ulkopuolella.

Perimmäinen kysymys kuitenkin on, miksi (vieraita, tuttuja, omia tai muiden) kieliä ylipäätään opiskellaan: jotta pystymme kommunikoimaan erilaisten ihmisten kanssa erilaisissa tilanteissa. Työ- ja yksityiselämän tarpeet ovat tässä mielessä loppujen lopuksi yhteneväiset.
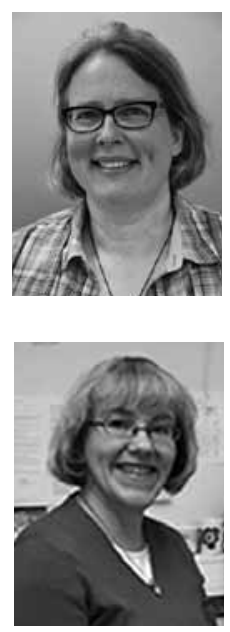

Taina Saarinen

tutkijatohtori (SA), dosentti

Soveltavan kielentutkimuksen

keskus

Jyväskylän yliopisto

Marita Härmälä

FT, tutkija

Soveltavan kielentutkimuksen

keskus

Jyväskylän yliopisto

\section{LÄHTEET}

Bacchi, C. (2000). Policy as discourse: what does it mean? Where does it get us? Discourse: Studies in the cultural politics of education 21 (1), 45-57.

Blommaert, J. (2007). Sociolinguistics and discourse analysis: Orders of indexicality and polycentrity. Journal of Multilingual Discourses 2, 115-130.

EK, Elinkeinoelämän keskusliitto (2010). Osaava henkilöstö - menestyvät yritykset. EK:n koulutusja työvoimapoliittiset linjaukset vuoteen 2015. Saatavissa: www.ek.fi/julkaisut.

Eteläpelto, A. (2009). Työidentiteetti ja subjektius rakenteiden ja toimijuuden ristiaallokossa. Teoksessa A. Eteläpelto, K. Collin \& J. Saarinen (toim.), Työ, identiteetti ja oppiminen. WSOYpro Oy Helsinki, 90-142.

Eurooppa 2020. http://ec.europa.eu/europe2020/ index_fi.htm

Hanhinen, T. (2010). Työelämäosaaminen: kvalifikaatioiden luokitusjärjestelmän konstruointi. Acta Universitatis Tamperensis; 1571. Saatavissa: http://acta.uta.fi/ pdf/978-951-44-8290-8.pdf

Heller, M. (2010). Language as a resource in the globalized new economy. Teoksessa N. Coupland (toim.), Handbook of language and globalization. Oxford, UK: Blackwell.

Heller, M. (2005). Language, skill and authenticity in the globalized new economy. Noves SL. Revista de Sociolingüística. Saatavissa: http://www6.gencat. net/llengcat/noves/hm05hivern/docs/heller.pdf

Härmälä, M. (2008). Riittääkö Ett ögonblick näytöksi merkonomilta edellytetystä kielitaidosta.

Kielitaidon arviointi aikuisten näyttötutkinnoissa. Saatavissa: https://jyx.jyu.fi/dspace/bitstream/ handle/123456789/18900/9789513933401. pdf?sequence $=1$

Julkunen, R. (2009). Työ - talouden ja minän välissä. Teoksessa A. Eteläpelto, K. Collin \& J. Saarinen (toim.), Työ, identiteetti ja oppiminen. WSOYpro Oy Helsinki, 18-48.

Kangasvieri, T., Miettinen, E., Kukkohovi, P. \& Härmälä, M. (2011). Kielten tarjonta ja kielivalintojen perusteet perusopetuksessa. Tilannekatsaus, joulukuu 2011.

Muistiot 2011:3, Opetushallitus. Saatavissa: http:// www.oph.fi/download/138072_Kielten_tarjonta_ja_ kielivalintojen_perusteet_perusopetuksessa.pdf 
Kangasvieri, T., Miettinen, E., Palviainen, H., Saarinen, T. \& Ala-Vähälä, T. (2011). Selvitys kotimaisten kielten kielikylpyopetuksen ja vieraskielisen opetuksen tilanteesta Suomessa: kuntatason tarkastelu. Jyväskylä: Soveltavan kielentutkimuksen keskus

Kela, M. \& Komppa, J. (2011) Sairaanhoitajan työkieli - yleiskieltä vai ammattikieltä? Funktionaalinen näkökulma ammattikielen oppimiseen toisella kielellä. Saatavissa: http://ojs.tsv.fi/index.php/pk/article/ view/4752/4470

Languages for Jobs (2011). http://ec.europa.eu/ languages/pdf/report.pdf

Lo Bianco, J. (2010). Language Policy and Planning. Teoksessa Hornberger, N. \& McKay, S. (toim.), Sociolinguistics and Language Education. Multilingual Matters.

Luukka, M.-R., Pöyhönen, S., Huhta, A., Taalas, P., Tarnanen, M. \& Keränen, A. (2008). Maailma muuttuu - mitä tekee koulu? Äidinkielen ja vieraiden kielten tekstikäytänteet koulussa ja vapaa-ajalla. Jyväskylän yliopisto, Soveltavan kielentutkimuksen keskus.

Martinheikki-Kokko, K. (2009). Monikulttuurisuuden haasteet työelämässä. Teoksessa A. Eteläpelto, K. Collin \& J. Saarinen (toim.), Työ, identiteetti ja oppiminen. Helsinki: WSOYpro Oy, 64-89.
OKM (2011). Koulutus ja tutkimus vuosina 2011-2016. Helsinki: Opetusministeriö.

Roberts, C. (2010). Language Socialization at the Workplace. Annual Review of Applied Linguistics, 30, 211-227.

Saarinen T. \& Välimaa, J. (2012) (tulossa). Change as an intellectual device and as an object of research. Teoksessa B. Stensaker, J. Välimaa \& C. S. Sarrico (toim.) Managing reform in universities: The dynamics of culture, identity and organisational change. Palgrave Macmillan.

Simons, M. \& Masschelein, J. (2008). The governmentalization of learning and the assemblage of a learning apparatus. Educational Theory 58 (4), 391-415.

Tuokko, E. (2009). Miten ruotsia osataan peruskoulussa? Perusopetuksen päättövaiheen ruotsin kielen B-oppimäärän oppimistulosten kansallinen arviointi 2008. Saatavissa: http://www.oph.fi/ download/116603_miten_ruotsia_osataan_ peruskoulussa.pdf

Virtanen, A. (2010). Onko filippiiniläisillä sairaanhoitajilla suomen kieli hallussa? Käsityksiä ammatillisesta kielitaidosta ja sen riittävyydestä hoivatyössä. Suomen kielen pro gradu -tutkielma. Jyväskylän yliopisto, kielten laitos.

\section{VIITE}

1. Taina Saarinen on toiminut edelleen toimintaansa jatkavan ryhmän jäsenenä huhtikuusta 2010. Ryhmän toimintaa koskevat kommentit ovat hänen havaintojaan 